\title{
Article
}

\section{Assessing the sociology of sport: On sports mega-events and capitalist modernity}

\author{
Horne, John David
}

Available at http://clok.uclan.ac.uk/13580/

Horne, John David ORCID: 0000-0003-4389-8204 (2015) Assessing the sociology of sport: On sports mega-events and capitalist modernity. International Review for the Sociology of Sport, 50 (4-5). pp. 466-471. ISSN 1012-6902

It is advisable to refer to the publisher's version if you intend to cite from the work. http://dx.doi.org/10.1177/1012690214538861

For more information about UCLan's research in this area go to http://www.uclan.ac.uk/researchgroups/ and search for <name of research Group>.

For information about Research generally at UCLan please go to http://www.uclan.ac.uk/research/

All outputs in CLoK are protected by Intellectual Property Rights law, including Copyright law. Copyright, IPR and Moral Rights for the works on this site are retained by the individual authors and/or other copyright owners. Terms and conditions for use of this material are defined in the policies page.

\section{CLoK}

Central Lancashire online Knowledge www.clok.uclan.ac.uk

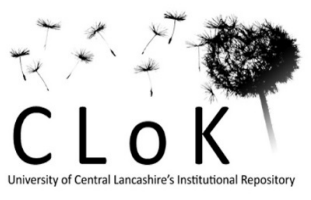




\section{Assessing the Sociology of Sport: On Sports Mega-Events and Capitalist Modernity}

\section{John Horne (“50@50” IRSS collection)}

One underlying assumption of this contribution, and the trajectory of much extant sociological research to date, is that just as modern competitive sport and large-scale sport events have developed in line with the logic of capitalist modernity, sports mega-events and global sport culture are now central to late modern capitalist societies. As media events, the Summer Olympic Games and the FIFA men's association football World Cup provide cultural resources for reflecting upon identity and enacting agency (for example on the Olympics see Billings 2008). ${ }^{i}$ Socially they provide resources for the construction of 'a meaningful social life in relation to a changing societal environment that has the potential to destabilize and threaten these things' (Roche 2000: 225). Structurally, sports mega-events produce new opportunities for commercial and property developers in urban areas, as well as experiential commodities important in the growth of consumer capitalism. In terms of policing they offer opportunities for experimentation in governance and the mass surveillance of mobile populations (Eick, 2011; Giulianotti and Klauser, 2010). Sports mega-events are also important elements in the orientation of nations to international or global society politically and symbolically. Hence sport, here in its mega-event form, comes to be an increasingly central, rather than peripheral, element of urban capitalist modernity (space prohibits a longer list but for further analyses of these topics see the edited collections by Horne and Manzenreiter 2002 and 2006; and Tomlinson and Young eds. 2006).

Maurice Roche's definition still provides the best way to understand mega-events sociologically - as 'large-scale cultural (including commercial and sporting) events, which have a dramatic character, mass popular appeal and international significance' (Roche 2000: 1). ${ }^{\text {ii }}$ For our purposes, two defining features of contemporary sports mega-events are first, that they are deemed to have highly significant social, political, economic and ideological consequences for the host city, region or nation in which they occur, and second, that they will attract considerable media coverage. By this 
definition therefore, an unmediated mega-event would be a contradiction in terms, and for this reason the globally mediated sports genre of mega-event has tended to supplant other forms of 'mega', such as World's Fairs or Expos, although these latter do continue to be enthusiastically hosted and attract substantial numbers of visitors.

Four issues with the concept 'sports mega-events' need to be clarified. First, with the obvious exception of the Olympics, it is arguable how many sports have championships that qualify as mega-events. Indeed, after the Olympics and the FIFA Football World Cup there is little agreement about which is the third largest sports 'mega'. The UEFA Euro (or as some would prefer, Euro ${ }^{\mathrm{TM}}$ ) Football Championship, the Rugby Union World Cup, and even the Ryder Cup golf competition between Europe and the USA, all claim to be the third biggest according to media audience. The cricket world cup has a vast media audience in South Asia, and obvious interest in the other cricket Test Match playing countries, but like the American Football Superbowl final, cricket has a relatively narrow fan-base, that makes it difficult to define it amongst the first rank of sports 'megas'.

A second question is how big does an event have to be to be described as 'mega'? There are different 'orders' of mega-event according to size, scope and reach of the sports involved, their geographical location and appeal. The most obvious measure is to refer to broadcast audience size. Yet if the size of an event is primarily related to the overall television audience, this is an estimated figure for much of the world. The difference between TV audience numbers claimed and those actually verifiable can be enormous. Hence whilst media audience size is a key driver of the definition, related promotional opportunities for hosts and corporate sponsors and the potential for the transformation of a location's infrastructure, also play a part in defining particular sports events as megas.

Third, when it comes to talking about 'events' we find that for many the actual live experience of the mediated spectacle can be a lot more mundane. The televised show is spectacular; but from the stands the small figures performing are often only recognizable because of TV screens in the stadium. Fourth, do we need the hyphen? It 
is useful to link mega and event because otherwise the three words have a habit of moving about - 'sports mega-event' can become 'mega sporting event'. Rather than using the word 'mega' to simply express that something is big or important, as it has come to be used in everyday speech, I suggest that research interest in sports megaevents should be understood as a specific social scientific focus on a particular genre of mega-event.

In the absence of a firmly shared definition of sports mega-events I am going to refer to six sporting spectacles that can be considered as 'first' and 'second order' megaevents: the Summer Olympic Games and the FIFA Men's Football World Cup constitute the first order of mega-events, and then follows the UEFA Euro (or as some would prefer, Euro ${ }^{\mathrm{TM}}$ ) Men's Football Championship, the Winter Olympics, the Commonwealth Games and the Pan-American Games. The development and expansion of these sports mega-events in the past thirty years, and especially the continuing ambition of varied locations in advanced and emerging capitalist economies to host sport spectacles, raises a number of pressing issues and challenges for our analyses. Examples include the gap between the rhetoric and reality of sports mega-event 'legacies' as revealed in the different forms of activism and resistance to them (Boykoff, 2014; Lenskyj 2008); the relationship between sports mega-events and social exclusion (Horne 2007); and the global power shifts that hosting sports mega-events in emerging capitalist economies outside the North reveal (Gruneau and Horne 2015). These issues raise questions that sociologists and other social scientists will need to consider when analyzing sports mega-events in the future, alongside four interlinked developments affecting them: increased frequency, expansion, proliferation, and hierarchical consolidation.

At the time of writing (March 2014) since 2000 there have been 21 editions of the sports mega-events mentioned earlier, staged in different continents throughout the world. Another 11 are planned to take place between June 2014 and 2022 (although, on the difficulty the Commonwealth Games has experienced in finding a host for its 2022 edition, see McLaughlin 2014). The rhythm and frequency of the four-year cycle of sports mega-events is indicative of the order and ranking of them. 'Lower order' megas, in terms of audience size, reach and impact, have been moved to 
accommodate to the rhythm of 'higher order' megas - hence the Winter Olympic Games were held in 1992 and 1994, and the Asian Football Confederation Championship was staged in 2004 and 2007 to adjust to a new cycle, avoid congestion with the higher order megas, and to maximize revenue and their potential audience reach. Since 1992, when the Summer and Winter Olympic Games took place in the same year for the last time, there has effectively been a two-year cycle of higher order sports mega-events. The Summer Olympic Games occupies the same year as the UEFA men's European Football Championship, whilst the Winter Olympics now shares its year with the FIFA men's football World Cup finals and the Commonwealth Games.

Despite the decision of the Olympic Programme Commission of the IOC in July 2005 to reduce the number of sports from 28 to 26 from the 2012 Summer Olympics, the IOC Congress Commission held in Copenhagen in October 2009 voted to add rugby sevens - a seven-a-side version of rugby union - and golf from 2016, and thus keep the number of events at 28 . It is evident that the size of these events, as well as the enthusiasm to host and participate in sports mega-events has grown in the past thirty years. This expansion and growing attraction of sports mega-events has been for several reasons, which also explains their proliferation.

New developments in the technologies of mass communication, especially the development of satellite television, have created the basis for global audiences for sports mega-events. The expansion of mega-events has been the formation of a sportmedia-business alliance that transformed professional sport generally in the late $20^{\text {th }}$ century. Through the idea of packaging, via the tri-partite model of sponsorship rights, exclusive broadcasting rights and merchandising, sponsors of the Olympics and the two biggest international football events have been attracted by the vast global audience exposure that sporting mega-events achieve. Interest in hosting sports megaevents has proliferated because they have become seen as valuable promotional opportunities for nations, cities and regions. The aim being to generate increased tourism, stimulate inward investment and promote both the host venues and the nation of which they are a part to the wider world as well as internally. Mega-events fit very well with consumption-based development strategies. 
Throughout the first half of the twentieth century the Olympics were exclusively hosted by cities in Western Nations. There was greater global variation in host cities for World Cups, largely due to the intensity of support for soccer in South America as well as FIFA's policy of spreading the event to its regional associations. Still, between the inception of the World Cup in 1930 and the end of the twentieth century the event was held in Western and Northern nations ten times in comparison to only five times in countries in the East or South. The geographical distribution of host cities for World's Fairs and major expositions in the twentieth century reveals a similar geographical trajectory. There were occasional international expositions in the colonies of the World Powers during the twentieth century but until the 1970s, the majority of host cities were located in the West and North. By the later stages of the twentieth century World's Fairs began to be awarded to Asian host cities, in particular, in greater numbers.

Since the turn of the twenty first century, there has been a trend for urban megaevents to be awarded to cities in the East and Global South. Yet this apparent opening out has also been accompanied by increasing hierarchical consolidation into capitalist modernity. The so called BRIC nations (Brazil, Russia, India and China) have been especially notable here, with the Olympics awarded to Beijing in 2008, Sochi in Russia in 2014, Rio de Janeiro in 2016, whilst the Youth Olympic Games have been awarded to Nanjing in 2014 and Buenos Aries in 2018 (on BRICs and sports megaevents see Curi et al, 2011; and Horne, 2011). Since 2000, Men's Football World Cups have been awarded to Brazil (2014), Russia (2018) and Qatar (2022), whilst the 2010 World's Fair was held in Shanghai and will be staged in Dubai in 2020. The correlation between growing economic ambition and event hosting appears to explain much of the attraction of global mega events for cities and countries in the East and Global South.

Whilst mega-events have routinely been viewed as economic stimulants that build infrastructure, provide jobs, attract tourists and convention goers, and leave positive legacies from enhanced visibility, to upgraded urban transportation, convention and sports facilities, hosting international mega-events also has a symbolic effect, 
announcing the status of the host city or country as an important site in global networks of political and economic power. In this sense, the increasing visibility of cities and countries in the East and Global South in the hosting of spectacular megaevents might arguably be taken as an indicator of global power shifts in an increasingly contingent world order.

Yet, it is important to note that there has also been ongoing controversy about the value, impact and legacy of global mega-events in Eastern and Southern nations, with critics questioning their effectiveness as avenues for economic development and the gap between the rhetoric and reality of the mega-event 'effect'. They claim that hosting such events is more likely to mean greater integration of aspiring nations into the economic legacy of late twentieth century neoliberalism. The pursuit of economic development and political influence through the hosting of large-scale urban spectacles has also been said to exacerbate the gap between rich and poor within the hosting cities or countries, whilst potentially deforming democratic governance by subjugating local authority to the power of so called 'business friendly international non-governmental organizations' ('BINGOs') that lack any meaningful form of political accountability. The increasing power and wealth of organizations such as FIFA and the IOC over the past three decades is arguably an example of such a vertical shift in power relations on a global scale.

At each of the sports mega-events that have taken place since 2000 we find debates over the following topics (Horne 2007: 86-91): the benefits of consumption-based development versus social redistribution policies; regeneration (or 'gentrification'); displacement (more accurately expressed as 'replacement') of local communities; public benefit versus private benefit; global impact versus local impact; spatial concentration of impacts; effects on employment and tourism; the manufacturing of consent by boosters; and the existence of 'opposition coalitions'. These topics will continue to be central to sociological and social science research in the future.

Some of the broader questions in need of further investigation in relation to sports mega-events therefore include: What are the economic, political and social risks and benefits of hosting such events? What implications, if any, can be drawn from analyses of recent spectacular events in the East and South for a broader 
understanding of changing relations of economic and political power on a global scale? To what extent do such events intervene in systems of governance at the local, national and international levels? What do such events tell us about the significance or the effectiveness of various forms of popular resistance to global power networks? What do such events tell us about the role of communications media in the early twenty first century political economy of global culture? 


\section{References}

Billings, A. (2008) Olympic Media: Inside the Biggest Show on Television. London: Routledge.

Boykoff, J. (2014) Activism and the Olympics: Dissent at the Games in Vancouver and London. New Brunswick: Rutgers University Press.

Curi, M., Knijnik, J. and Mascarenhas, G. (2011) 'The Pan American Games in Rio de Janeiro 2007: Consequences of a sport mega-event on a BRIC country', International Review for the Sociology of Sport 46 (2) pp. 140-156.

Eick, V. (2011) 'Lack of Legacy? Shadows of surveillance after the 2006 FIFA World Cup in Germany' Urban Studies 48 (15): 3329-3345.

Giulianotti, R. and Klauser, F. (2010) 'Security Governance and Sport Mega-Events:

Toward an Interdisciplinary Research Agenda', Journal of Sport and Social Issues 34 (1) pp. 49-61.

Gruneau, R. \& Horne, J. Eds. (2015) Mega-Events and Globalization: Capital, Cultures and Spectacle in a Changing World Order. London: Routledge.

Horne, J. (2011) 'Building BRICs by Building Stadiums: Preliminary Reflections on Recent and Future Sports Mega-Events in Four Emerging Economies'. Available at http://www.bl.uk/sportandsociety/exploresocsci/sportsoc/mega/buildingbricks.pdf [last accessed 26 March 2014].

Horne, J. (2007) 'The Four 'Knowns' of Sports Mega-Events', Leisure Studies 26 (1) pp. 81-96.

Horne, J. and Manzenreiter, W. Eds. (2006) Sports Mega-Events: Social Scientific Analyses of a Global Phenomenon. Oxford: Blackwell.

Horne, J. and Manzenreiter, W. Eds. (2002) Japan, Korea and the 2002 World Cup. London: Routledge.

Lenskyj, H. (2008) Olympic Industry Resistance: Challenging Olympic Power and Propaganda. Albany: State University of New York (SUNY) Press.

McLaughlin, C. (2014) 'Commonwealth Games: Lack of interest in hosting future Games'. Available at http://www.bbc.co.uk/sport/0/commonwealth-games/25832867 [last accessed 26 March 2014]. 
Müller, M. (2013) 'The seven deadly sins of mega-event planning - and what to do about them'. Lecture given at Kazan Federal University on 14 October 2013. Available from www.martin- muller.net [last accessed 26 March 2014].

Roche, M. (2000) Mega-Events and Modernity. London: Routledge.

Tomlinson, A. and Young, K. Eds. (2006) National Identity and Global Sports

Events: Culture, Politics and Spectacle in the Olympics and the Football World Cup. Albany: State University of New York (SUNY) Press.

\title{
Endnotes
}

\begin{abstract}
i Although it has become conventional to refer to the 'Olympic and Paralympic Games', as hosts of both Summer and Winter editions of the Games are now expected to also host the Paralympic event three to four weeks after the 'main event', I do not address the specifics of this event here.

ii Research into mega-events is not however the monopoly of sociology. Other social sciences interested in the challenge of investigating mega-events, in their sporting or other guises (religious, cultural, political to name just a few), include anthropology, economics, geography, media studies, planning, political science and urban studies. Partly as a result there is no single agreed upon definition of 'mega-event'. For example, economic geographer Martin Müller (2013) suggests that mega-events might include international religious gatherings, political and economic summits, as well as cultural events.
\end{abstract}

